http://ojs.umrah.ac.id/index.php/kiprah

\title{
Kemampuan Menulis Ringkasan Teks Cerita Siswa Kelas VII Siswa Sekolah Menengah Pertama Kota Tanjungpinang Tahun 2019
}

\author{
Wahyu Indrayatti* \\ Pendidikan Bahasa dan Sastra Indonesia, Universitas Maritim Raja Ali Haji, Tanjungpinang, Kepulauan Riau, \\ Pengiriman: 26/02/2020; Diterima: 26/06/2020; Publikasi: 30/06/2020 \\ DOI: https://doi.org/10.31629/kiprah.v8i1.2072

\begin{abstract}
Abstrak
Penelitian ini bertujuan mendeskripsikan kemampuan menulis ringkasan teks cerita siswa kelas VII Sekolah Menengah Pertama Kota Tanjungpinang, Provinsi Kepulauan Riau. Penelitian ini menggunakan metode deskriptif dengan pendekatan kuantitatif. Teknik pengumpulan data penelitian menggunakan teknik tes dengan melibatkan 30 siswa dengan kemampuan meringkas terbaik yang mewakili 15 Sekolah Menengah Pertama di kota Tanjungpinang yang diambil secara acak. Teknik analisis data menggunakan studi dokumen. Kemampuan menulis teks ringkasan dilihat dari lima aspek, yaitu: kesesuaian isi, ketepatan detail cerita, ketepatan pengembangan alur, ketepatan dalam kalimat, dan ketepatan gaya penuturan. Berdasarkan hasil analisis, dapat disimpulkan bahwa sebagian besar siswa memiliki kemampuan sangat baik dalam meringkas teks cerita hal tersebut dilihat dari frekuensi nilai siswa, 23 siswa (77\%) termasuk kategori sangat baik dengan perolehan nilai 80-100 dengan nilai rata-rata 81,5 . Siswa memiliki kemampuan paling baik pada aspek gaya penceritaan dan kemampuan paling rendah pada aspek ketepatan kata dan tata kalimat.
\end{abstract}

Kata Kunci : menulis; ringkasan cerita; teks cerita

\begin{abstract}
This study aims to describe the seventh grade students ability in writing summary text.This research uses a descriptive method with a quantitative approach. The research data collection technique used a test technique involving 30 students with the best summarizing ability representing 15 junior high schools in Tanjungpinang, taken randomly. Data analysis techniques using document studies. The students ability is seen by five aspects : appropriateness of content, accuracy of story details, accuracy of plot development, accuracy in sentences and accuracy of narrative style. Based on the results of the analysis, it can be concluded that the majority of students have very good abilities in summarizing story text. Students have the best ability in the aspect of storytelling style and the lowest ability in aspects of the accuracy of words and sentence structure.
\end{abstract}

Keywords : writing; summary texte; narrative

\section{PENDAHULUAN}

Meringkas teks cerita merupakan kegiatan biasa dilakukan siswa. Guru sering memberikan tugas kepada siswa menulis sebuah teks ringkasan dari novel atau buku cerita yang telah dibaca baik pada pembelajaran bahasa maupun kegiatan literasi. Selain itu, kegiatan meringkas tidak hanya dilakukan pada pembelajaran bahasa saja tetapi juga dilakukan siswa dalam mempelajari mata pelajaran lainnya.

Isdriani (2009) berpendapat bahwa ringkasan atau precis adalah suatu cara yang efektif untuk menyajikan suatu karangan dalam bentuk singkat. Suatu ringkasan disajikan dalam bentuk yang lebih pendek dari 
tulisan aslinya dengan berpedoman pada keutuhan topik dan gagasan yang ada dalam tulisan aslinya yang panjang. Sejalan dengan Isdriani, Nurhadi (2010) mengemukakan bahwa ringkasan adalah bentuk singkat atau ringkas, dari sebuah karangan yang masih memperlihatkan sosok dasar dari aslinya. Keraf dalam Wahyuni (2017) menjelaskan bahwa ringkasan merupakan bentuk penyajian singkat dari suatu karangan asli, tetapi tetap mempertahankan urutan isi dan sudut pandang pengarang asli, sedangkan perbandingan bagian atau bab dari karangan asli secara proporsional tetap dipertahankan dalam bentuknya yang singkat. Meringkas ialah menulis kembali teks menjadi lebih pendek dengan memangkas hal-hal yang lebih kecil yang menyelimuti gagasan utama bacaan sehingga kerangka dasarnya tampak jelas.

Fungsi ringkasan adalah untuk mengetahui dan memahami gagasan utama dan tujuan penulis melalui tulisannya seperti buku, artikel, dan lain-lain secara keseluruhan dengan cepat dan singkat. Dalam sebuah teks terdiri atas beberapa pikiran dari seorang penulis, sebagian pembaca pasti tidak akan membuang waktunya untuk membca keseluruhan isi dari tulisan tersebut, apalagi tulisan tersebut sangat panjang dan sulit dipahami. Dalam meringkas, keindahan gaya bahasa, ilustrasi, serta penjelasan-penjelasan yang rinci dihilangkan sehingga jadilah sari tulisan tanpa hiasan dengan tetap mempertahankan urutan pikiran penulis asli beserta pendekatannya. Keraf dalam Olivia (2009) menyatakan tujuan meringkas ialah dapat berguna untuk mengembangkan ekspresi serta penghematan kata. Menulis ringkasan melatih siswa mempertajam daya kreasi dan konsentrasi.

Keraf dalam Wahyuni (2017) merincikan tahapan dalam meringkas teks sebagai berikut: 1) Langkah pertama ialah membaca teks yang akan diringkas secara berulang kali untuk mengetahui kesan umum secara menyeluruh. Penulis ringkasan perlu juga mengetahui maksud dan sudut pandang pengarang; 2) Bila penulis sudah menangkap maksud, kesan umum isi teks, dan sudut pandang pengarang berikutnya ialah memperdalam dan mengkonkretkan informasi yang didapatkan dengan membaca kembali setiap paragraf sambil mencatat semua gagasan yang penting dari setiap paragraf; 3) Dengan berbekal kesan umum pada langkah pertama dan catatan-catatan pada langkah kedua, penulis sudah siap memulai menulis ringkasan. Catatan yang sudah dibuat merupakan pedoman unuk menyusun kalimatkalimat yang baru, merangkaikan semua gagasan ke dalam suatu wacana yang jelas, dan menggambarkan kembali isi karangan asli; 4) langkah keempat adalah penulis memeriksa kembali tulisannya dengan memerhatikan beberapa hal sebagai berikut: (a) Sebaiknya dalam menulis ringkasan menggunakan kalimat tunggal karena kalimat majemuk menunjukkan adanya dua gagasan atau lebih yang bersifat pararel; (b) Bila memungkinkan kalimat sebaiknya diringkas menjadi frasa, frasa menjadi kata. Begitu juga rangkaian gagasan panjang hendaknya diganti dengan gagasan sentral saja; (c) Jumlah alinea tergantung jumlah topik utama yang akan dimasukkan dalam ringkasan; (d) Bila mungkin semua keterangan atau kata sifat dibuang; kadang-kadang kata sifat atau keterangan masih harus dipertahankan untuk menjelaskan gagasan umum yang tersirat dalam rangkaian keterangan atau sifat yang terdapat dalam teks; (e) Pertahankan susunan gagasan asli, serta ringkaslah gagasan-gagasan tersebut dalam urutan seperti teks asli; (f) Dalam meringkas, bahasa langsung berubah menjadi bahasa tak langsung ditulis dengan sudut pandang orang ketiga; (g) Hasil ringkasan memenuhi ketentuan jumlah kata atau panjang ringkasan.

Teks cerita termasuk dalam kategori teks narasi (pencitraan atau pengisahan). Narasi adalah ragam wacana yang menceritakan proses kejadian suatu peristiwa. Keraf (2007) mengatakan bahwa karangan narasi merupakan suatu bentuk karangan yang sasaran utamanya adalah tindak tanduk yang dijalin dan dirangkai menjadi sebuah peristiwa 
yang terjadi dalam suatu kesatuan waktu. Ini juga dapat dirumuskan dengan cara lain; narasi adalah suatu bentuk karangan yang berusaha menggambarkan sejelas-jelasnya kepada pembaca suatu peristiwa yang telah terjadi. Saddhono (2012) menjelaskan sasaran narasi adalah memberikan gambaran yang sejelasjelasnya kepada pembaca mengenai fase, urutan, langkah, atau rangkaian terjadinya sesuatu hal, narasi dikenal sebagai cerita. Karangan narasi terdapat peristiwa atau kejadian dalam satu urutan waktu. Narasi memiliki tiga unsur pokok yaitu: peristiwa atau kejadian, tokoh, dan konflik. Jika ketiga unsur itu bersatu, ketiga unsur itu disebut plot atau alur. Jadi, narasi adalah cerita yang dipaparkan berdasarkan plot atau alur. Dengan demikian, ringkasan cerita yang baik ialah : 1) Teks lebih pendek dari teks asli ; 2) Tidak merubah isi cerita dan sudut pandang cerita penulis ; 3) Berisi intisari atau gagasan penting cerita; 3) Mempertahankan gagasan asli baik kejadian tokoh utama dan konflik ; 4) Bahasa langsung berubah menjadi bahasa tidak langsung dengan sudut pandang orang ketiga.

Meringkas merupakan proses kognitif, Menurut beberapa ahli dalam Ampuni (1998) Siu berpendapat bahwa membaca merupakan suau aktivitas bertujuan yang membutuhkan pengaturan kemampuan kognisi seperti pengartian lambang dan pemahaan. Dari sumber yang sama Thorndike juga mengemukakan bahwa membaca, seperti halnya proses berpikir, melibatkan proses pembelajaran, refleksi, penilaian, analisis, sintesis, pemecahan masalah, seleksi, pengambilan keputusan, organisasi, perbandingan, penentuan hubungan, dan evaluasi kritis terhadap bacaan. Sementara itu Anderson dan Pearson menyatakan bahwa aktivitas membaca menuntut pelakunya untuk membuat kesimpulan-kesimpulan dengan mengintegrasikan pengetahuan-pengetahuan yang ada sebelumnya.

Demikian juga dengan menulis, merupakan proses berpikir Flower dalam Sibarani (2017), mengemukakan bahwa menulis adalah proses kognitif yang mana penulis harus memiliki lima jenis atribut, yakni: (a) memori jangka panjang, (b) pengetahuan tentang topik, (c) pengetahuan tentang calon pembaca, (d) rencana penulisan dan (e) pengetahuan tentang sumber bacaan.

Penelitian ini bertujuan
mendeskripsikan kemampuan siswa dalam menulis teks ringkasan cerita Hikayat Gangsa dan Putri Malu yang ditulis oleh siswa Sekolah Menengah Pertama kelas VII. Cerita tersebut terdiri dari sekitar 30000 kata yang terdiri atas 10 subjudul yaitu : 1) "Gangsa Anak Yatim"; 2) "Berguru Kepada Kakek"; 3) "Perjalanan"; 4) "Negeri Banjit" ; 5) "Melawan Raksasa"; 6) "Akal Gangsa"; 7) "Bertemu Putri Malu"; 8) "Utusan dari Negeri Kasui"; 9) "Jurus Rendah Hati"; dan 10) "Melawan Kawanan Gajah". Kemampuan tersebut dilihat dari lima aspek: kesesuaian isi, ketepatan detail cerita, ketepatan pengembangan alur, ketepatan kata dan kalimat, dan gaya penuturan (penulisan) Nurgiantoro (2014).

\section{METODE PENELITIAN}

Penelitian ini merupakan penelitian deskriptif dengan pendekatan kuantitatif. Kemampuan meringkas teks siswa kelas VII Sekolah Menengah Pertama di Kota Tanjungpinang. Data penelitian adalah teks ringkasan cerita dari 30 siswa yang direkomendasikan oleh guru. Siswa-siswa tersebut berasal dari 15 sekolah di kota Tanjungpinang yang diambil secara acak.

Metode pengumpulan data dengan teknik tes. Teknik analisis teks dilakukan dengan studi dokumen. Peneliti menganalisis teks ringkasan yang telah dikumpulkan oleh siswa. Selanjutnya data tersebut dianalisis berdasarkan indikator meringkas teks cerita. Langkah-langkah analisis yang dilakukan ialah sebagai berikut: 1) Meraduksi data dengan menyeleksi dan mengklasifikasikan data; 2) Pemaparan data, memaparkan data yang dianalisis; dan 3) Kesimpulan akhir.

\section{HASIL DAN PEMBAHASAN}

Pembahasan dalam penelitian ini, memaparkan kemampuan siswa menulis teks ringkasan cerita. Kemampuan tersebut dilihat lima aspek, yaitu: 1) Kesesuaian isi cerita; 2) Ketepatan detail cerita; 3) Ketepatan 
pengembangan alur; dan 4) Ketepatan kata dan kalimat dan 5) Gaya penuturan.

Data pada penelitian ini ialah berupa skor yang diperoleh dari olah data yang telah dilakukan pada teks ringkasan siswa. Pada aspek pertama kesesuaian isi cerita, 16 siswa mencapai skor 4, dan 14 siswa mencapai skor 3. Aspek ketepatan detail cerita 14 siswa mencapai skor 4, 13 siswa mencapai skor 3,1 siswa mendapat skor 2, dan 2 siswa mendapat skor 1 . Berikutnya aspek ketepatan pengemban alur, 11 siswa mencapai skor 4,8 siswa mencapai skor 3, 9 siswa mendapat skor 2 dan 2 siswa mendapat skor 1 . Aspek ketepatan kata dan tata kalimat, 6 siswa mencapai skor 4, 9 siswa mencapai skor 3,12 siswa mencapai skor 12 dan 3 siswa mendapat skor 1 dan pada gaya penceritaan, siswa 30 siswa mencapai skor 4. Ringkasan data dapat dilihat pada Gambar 1.

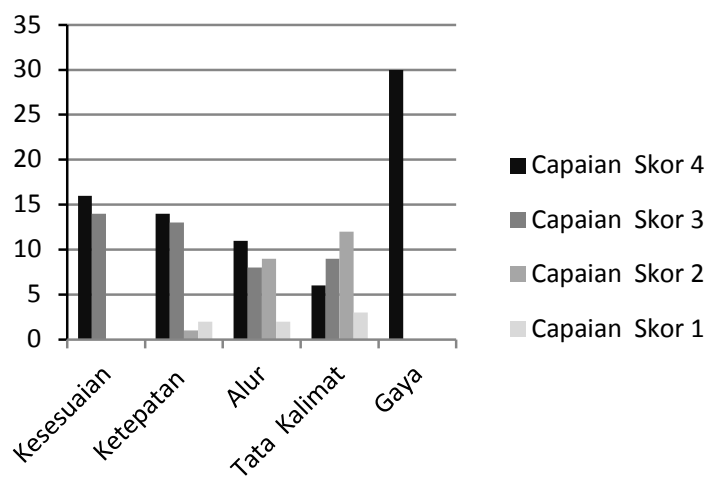

Gambar 1. Capaian Skor Siswa Berdasarkan aspek kemampuan siswa dalam menulis teks ringkasan cerita

\section{Kesesuaian Isi Cerita}

Berdasarkan hasil analisis dari 30 data yang telah terkumpul, secara garis besar isi teks ringkasan cerita yang ditulis siswa memiliki kesesuaian isi. 16 siswa (53\%) dapat menceritakan kembali dengan lebih ringkas secara tertulis sesuai dengan jalan cerita pada teks cerita asli. Semua isi ringkasan diawali dengan menceritakan kelahiran Gangsa, kemudian Gangsa berguru silat pada sang kakek, Gangsa melakukan perjalanan untuk belajar jurus paling hebat ke Negeri Banjit, Gangsa tiba di Negeri Banjit, Perlawanan
Negeri Banjit melawan raksasa, Akal Gangsa untuk mengalahkan para raksasa, Gangsa diangkat menjadi pangeran, Kedatangan utusan dari Kerajaan Negeri Kasui untuk meminta Gangsa pulang dan Negeri Kasui menghadapi serbuan kawanan gajah. Sebanyak 14 siswa (47\%) mendapatkan skor 3 karena dalam teks ringkasan yang mereka tulis, ditemukan ketidaksesuaian isi cerita tidak lebih dari 5 kesalahan dan tidak mengubah jalannya alur cerita.

"...seorang bayi yang dilahirkan dengan yatim karena ayahnya tidak pulang" (32A/1)

Dalam teks asli, Ayah Gangsa itu sudah meninggal enam bulan sebelum ia lahir.

"Dan saat istirahat Gangsa bertanya kepada kakeknya, "Kakek Ilmu apa yang paling hebat?". Kakek pun menjawab ilmu harimau dan ilmu rendah hati....". (28 A/2)

Percakapan tersebut tidak sesuai dengan percakapan pada teks asli. Karena pada teks kakek yang bertanya pada Gangsa tentang jurus silat paling hebat, namun jawaban Gangsa tidak ada yang benar. Dan kakek memberi tahu jawabannya.

\section{Ketepatan detail cerita}

Ketepatan detail cerita dilihat dari rangkaian peristiwa penyusun cerita pada setiap subjudul. Peristiwa-peristiwa tersebut merupakan kegiatan atau hal-hal berkenaan dengan tokoh utama dalam cerita yaitu Gangsa. Kemudian aspek ketepatan detail cerita 14 siswa mencapai skor 4 , dengan kualifikasi isi ringkasan terpusat pada tokoh utama Gangsa dengan penceritaan sesuai dengan subjudul dan terdapat kekurangan detail tidak lebih dari 5 peristiwa, 13 siswa mencapai skor 3 dengan kualifikasi terdapat kekurangan detail sebanyak 6 hingga 10 peristiwa, 1 siswa mendapat skor 2, dengan kualifikasi terdapat kekurangan detail sebanyak 11 hingga 15 kesalahan dan 2 siswa mendapat skor 1, kualifikasi kekurangan detail cerita sebanyak 15 peristiwa. Berikut ringkasan setiap subjudul yang diambil dari beberapa teks ringkasan siswa:

\section{Gangsa Anak Yatim}

Penceritaan dimulai dengan kelahiran Gangsa 
di pagi hari, nama Gangsa diberikan oleh Ibunya dari nama almarhum ayahnya. Gangsa sejak lahir tinggal bersama Ibu dan kakeknya.

"Pagi yang cerah menghiasai Negeri Kasui salah satu rumah di negeri Kasui itu terlihat bahagia, karena telah lahir seorang anak lelaki tampan. Rumah itu adalah rumah bu Miah. Anak lelaki itu diberi nama Gangsa, oleh Ibu Miah. Ibu Miah memberinya nama Gangsa karena itu adalah nama mendiang suaminya yang telah meninggal. Gangsa menjadi anak yatim sejak lahir dan dirawat oleh ibu serta kakeknya" (10A/1)

\section{Berguru Kepada Kakek}

Kemudian Gangsa berguru kepada kakek yang merupakan guru silat, sebagai murid Gangsa diperlakukan seperti murid lainnya, hingga suatu ketika kakek memberitahunya tentang menguasai jurus paling hebat yaitu jurus rendah hati yang tidak bisa diajarkan oleh orang lain dengan melakukan perjalanan ke negeri Banjit.

"Setelah ia telah beranjak 10 tahun, dia merupakan anak yang mahir dalam silat yang diajarkan oleh kakeknya. Lalu, kakeknya menawarkan satu jurus hebat untuk dipelajarinya.Kakeknya memberitahu jika jurus itu bernama jurus rendah hati. Namun, dia harus mempelajarinya dari dirinya sendiri dengan berjalan jauh dari negeri Kasui menuju negeri Banjit. Dia langsung meminta izin kepada Ibunya untuk perjalanan tersebut. Ibunya memperbolehkannya." (33A/2)

\section{Perjalanan}

Esok harinya berbekal nasi lemang dan air nira dari ibunya, Gangsa berangkat ke negeri Banjit. Di tengah perjalanan ia bertemu dengan seorang laki-laki paruh baya di sebuah pondok-pondok. Lelaki itu meminta gangsa menukar sisa nasi lemangnya dengan singkong ajaib. Kemudian di sebuah sungai ia bertemn dengan seorang wanita seusia ibunya yang sedang mencuci sebuah labu. Pada akhir percakapan mereka, wanita tersebut meminta gangsa menukar sisa air niranya dengan air di dalam sebuah labu, air tersebut merupakan air obat yang sangat mujarab mengobati berbabagi penyakit dengan meminumnya sebanyak tiga teguk.

“ Setelah mendapat restu, Ia pun berangkat dengan membawa bekal nasi lemang dan air nira.Hampir dua jam berjalan, ia merasa lelah. Ia berjalan lewat hutan dan di perladangan ia menemui pondok. Disitulah ia beristirahat. Pemilik pondok ingin menukar nasi lemang Gangsa dengan dua singkong yang pemilik pondok miliki. Sebelumnya Gangsa tidak mau, setelah dia berfikir dan mengingat perkataan kakek, ia pun mau menukarnya. Gangsa pun melanjutkan perjalanan dan meninggalkan pondok itu. Di tengah perjalanannya ada yang berbicara bahwa singkong yang ia dapatkan tadi adalah singkong ajaib. Ia pun berjalan ke arah selatan dan bertemu dengan seorang bibi di sungai. Bibi ingin menukarkan air nira Gangsa dengan air bibi. Gangsa teringat tentang keajaiban singkong itu. Ia bersedia menukar air nira dengan air bibi. Tak lama berjalan, ia mendengar suara bibi dan berkata bahwa air itu dapat menyembuhkan penyakit. Tetapi orang yang berbicara ini tidak nampak wujudnya. Ia terus melanjutkan perjalanannya." (21A/3)

\section{Negeri Banjit}

Negeri Banjit dipimpin oleh seorang raja yang disenangi oleh seluruh rakyatnya. Sang raja memiliki seorang putri bernama Putri Malu. Negeri tersebut sedang dirundung masalah berkepanjangan. Para raksasa dari negeri atas gunung membuat resah rakyat Banjit karena mengambil persediaan makanan di lumbung dan hewan ternak milik penduduk. Kedatangan raksasa sebelumnya telah menyebabkan kaki sang Putri terkilir saat akan bersembunyi. Raja sedang bermuram durja karena memikirkan kondisi kaki putrinya yang tidak kunjung sembuh dan rumit belum menemukan cara untuk mengusir para raksasa pada malam purnama berikutnya datang menagih permintaannya 100 ekor sapi, bila tidak dipenuhi mereka akan menghancurkan negeri Banjit. Panglima mengusulkan pada raja untuk menyerang para raksasa dengan menembakkan ratusan anak panah.Usulan panglima diterima oleh raja dan raja sendiri yangakan memimpin penyerangan itu. 
"Gangsa melanjutkan perjalanannya. Gangsa pun sampai di negeri yang dituju. Negeri itu dipimpin seorang raja yang bijaksana, dan memiliki anak bernama putri malu. Ternyata negeri itu sedang dilanda musibah. Pada bukan purnama segerombolan raksasa akan datang menyerbu hewan ternak dan melukai putri Malu. Raksasa datang untuk meminta seratus ekor sapi. Namun raja ndak menerima kedatangan raksasa dan berusaha mengusir raksasa tersebut. Pengawal mengusulkan untuk menyerbu raksasa dengan ratusan anak panah yang berapi. Usualn itu diterima oleh raja. Namun raja ingin memimpin pasukan."(12 $\mathrm{A} / 4$ )

\section{Melawan Raksasa}

Ketika Gangsa tiba di kota Negeri Banjit hari sudah petang. Suasana kota tampak sepi tidak berpenghuni. Gangsa bertemu dengan seorang prajurit dan menyampaikan maksud kedatangannya. Kemudian, prajurit itu bercerita tentang masalah yang sedang melanda negeri Banjit. Akhirnya Gangsa dibawa oleh prajurit itu kepada raja. Tidak lama Gangsa bercakap-cakap dengan raja, terasa bumi bergetar petanda para raksasa datang untuk menagih permintaanya. Prajurit bersiap menyerang dengan ratusan anak panah, namun beberapa kali serangan panah itu tidak membuat para raksasa takut dan serangan itu tidak berhasil sedangkan persediaan anak panah semakin menipis.

"Ternyata dugaan Gangsa benar. Panah panah tidak dapat menembus 15 tubuh raksasa itu dan panah berapi membakar rumah warga. Melihat raja yang tidak akan kabur bila prajuritnya tidak ikut." (7A/5)

\section{Akal Gangsa}

Melihat serangan demi serangan yang dilakukan pasukan td mempan, munculah akal Gangsa.Gangsa mendapat akal untuk mengikat kaki para raksasa satu sama lainnya saat mereka sibuk menangkis anak panah api.Setelah memakan singkong ajaib, Gangsa dibantu beberapa prajurit mengikat kaki para rakasasa. Kaki para raksasa berhasil diikat satu sama lain. Hasilnya tidak mengecewakan, ikatan itu membuat raksasa- raksasa bertumbangan dan saling menghimpit. Kemudian Gangsa dan beberapa prajurit bergegas mengikat tangan mereka akibatnya mereka tidak bisa bergerak lagi hingga datang fajar. Cahaya matahari melemahkan mereka dan akhirnya mereka mati dan mengeras seperti batu. Baginda raja dan prajurit-prajurit penuh suka cita karena terbebas dari beban maha berat yang selama ini meresahkan seluruh Negeri Banjit.

"Dan ketika bulan purnama raja menyiapkan rencananya untuk melawan raksasa. Dan usahapun sia-sia. Dan datanglah Gangsa, ia memiliki akal untuk melawan raksasa.Ia meminta kepada raja agar mencari tali rotan. Mereka pun mendapatkan tali rotan itu dan mengikatnya pada kaki raksasa itu. Akhirnya raksasa itu terjatuh dan tidak bisa bangkit. Usaha Gangsa dan Panglima pun berhasil."(5A/6)

\section{Bertemu Putri Malu}

Berkat akal Gangsa akhirnya Negeri Banjit kembali aman dan tentram. Banginda raja mengangkat Gangsa sebagai anak dengan diberi gelar pangeran dan tinggal di Istana. Gangsa menjadi saudara Putri Malu. Akhirnya kaki Putri Malu dapat disembuhkan dengan air labu pemberian wanita yang Ia jumpai di sungai. Kemudian Gangsa dan Putri Malu memberikan sisa air labu iu kepada semua prajurit yang cedera pada pertempuran melawan raksasa dan dengan meminum masing-masing tiga teguk satu persatu prajurit pun sembuh.Air ajaib di dalam labu habis tidak tersisa.

"Keesokan harinya setelah berhasil mengalahkan raksasa Gangsa pun diangkat menjadi pangeran. Setelah itu Gangsa langsung menghampiri Putri Malu agar bisa meminum air labu tersebut agar kakinya yang terkilir sembuh". (1A/7)

\section{Utusan Negeri Kasui}

Tidak terasa sertahun telah berlalu, Gangsa tinggal di Istana Negeri Banjit. Suatu hari datanglah dua prajurit utusan kerajaan Kasui untuk meminta Gangsa pulang. Pada saat itu, negeri Kasui sedang mendapatkan musibah setiap tiga minggu kawanan gajah melintasi 
negeri kasui. Kawanan gajah itu melanda dan merobohkan rumah-rumah serta merusak kebun dan perladangan.Gangsa diminta untuk membantu menghalau gajah-gajah tersebut agar Negeri Kasui kembali tentram seperti sediakala. Dengan berat hati Baginda raja mengizinkan Gangsa pulang dan raja pun mempersiapkan seribu lima ratus prajurit untuk membantu Negeri Kasui.

"Setelah bertahun-tahun ia disuruh pulang ke Negerinya yaitu Negeri Kasui. Karena ia ingin membantu negerinya dengan serangan Gajahgajah yang melakukan keonaran dengan merobohkan rumah para penduduk. Serta menziarah ke kubur kakeknya yang telah meninggal dalam beberapa bulan lalu"(32A/ 8)

\section{Jurus Rendah Hati}

Sesampai di Negeri Kasui, Gangsa langsung menuju Istana negeri Kasui untuk menghadap raja dan menitipkan pasukan yang ia bawa dari Negeri Banjit. Kemudian Gangsa segera menemui ibunya. Gangsa menyampaikan pada ibunya bahwa ia belum berhasil mendapatkan jurus rendah hati.Gangsa akhirnya memahami apa yang dimaksud dengan jurus rendah hati sudah ada pada dirinya selama melakukan perjalanan ke Negeri Banjit. Ia hanya perlu berusaha menghilangkan sifat sombong dan angkuh agar dapat menguasai jurus rendah hati.

"Gangsa langsung meminta izin kepada raja untuk pulang ke Negeri Kasui . Sesampainya disana ia langsung menemui ibunya dan berkata kalau dia belum mendapat jurus rendah hati. Ibunya tetap memberikannya semangat. Setelah dia pikirkan,mungkin yang dilakukan selama ini adalah jurus rendah hati" (12A/9)

\section{Menghadapi Kawanan Gajah}

Dengan dua ribu prajurit, raja Negeri Kasui berencana akan menghalau kawanan gajah. Namun Gangsa tidak sependapat dengan cara raja yang menggunakan kekerasan. Setelah beberapa lama dalam perdebatan, akhirnya raja mengalah dan mengikuti saran Pangeran Gangsa. Rajapun memerintahkan agar penduduk menutup daerah perladangan lama yang dilintasi oleh kawanan gajah. Seminggu kemudian perkataan Gangsa terbukti. Tidak ada lagi kawanan gajah yang menerobos Negeri Kasui. Negeri Kasui pun aman tentram seperti sedia kala.

"Keesokan harinya Gangsa menemui raja dan raja berkata seminggu lagi gajah-gajah itu akan melewati negeri ini. Raja ingin menyerang dengan dua ribu pasukan. Tapi Gangsa meminta raja untuk menutup ladang yang biasanya menjadi tempat lalu lalang gajah dan dengan terpaksa raja menutupnya karena hanya memiliki sedikit pasukan. Seminggu kemudian ternyata memang benar gajah-gajah itu tidak lagi menyerang Negeri Kasui dan Negeri ini mejadi aman seperti dulu lagi" (Data 35A/10)

\section{Ketepatan pengembangan alur}

Berikutnya aspek ketepatan pengemban alur, 11 siswa mencapai skor 4 , teks ringkasan menggunakan pengembangan alur maju sesuai dengan alur dalam cerita Hikayat Gangsa dan Putri Malu, dimulai dari alur perkenalan dimulai dengan Gangsa Anak Yatim, Berguru Kepada Kakek, dan Perjalanan. Tahap kemunculan konflik pertama terdapat pada subjudul Negeri Banjit. Kemudian tahap klimaks pertama terdapat pada bagian Melawan Raksasa dan Akal Gangsa. Konflik menurun diceritakan dalam subjudul Bertemu dengan Putri Malu. Kemudian kemunculan konflik kedua terdapat pada bagian Utusan Negeri Kasui dan Jurus Rendah Hati puncak konflik dan penyelesaian kedua terdapat pada subjudul terakhir yaitu Melawan Kawanan Gajah. 8 siswa mencapai skor 3 dengan kualifikasi alur maju, namun tidak lengkap terdapat kesalahan alur cerita namun tidak mempengaruhi alur cerita asli. siswa mendapat skor 2 terdapat cukup banyak kesalahan alur cerita yaitu 5 kesalahan jalan cerita dan 2 siswa mendapat skor 1, terdapat lebih daari 5 kesalahan alur cerita.

\section{Ketepatan kata dan kalimat}

Kata dan kalimat memiliki fungsi yang sangat penting dalam penulisan sebuah karangan termasuk teks ringkasan cerita. Pada aspek ketepatan kata dan tata kalimat, 6 siswa mencapai skor 4 dengan kesalahan terkait 
ejaan, pilihan kata dan kalimat paling banyak 5 kesalahan, 9 siswa mencapai skor 3 dengan kesalahan sebanyak 5 samapai 10 kesalahan, 12 siswa mencapai skor 2, dengan kualifikas terdapat sebanyak $10-15$, dan 3 siswa mendapat skor 1, dengan banyak kesalahan ejaan dan tata kalimat lebih dari 20 kesalahan.

Kesalahaan-kesalahan yang ditemukan dalam teks ringkasan siswa ialah berkaitan dengan Ejaan. 1) Banyak sekali kesalahan penulisan nama orang, tempat. Dan pada permulaan kalimat yang seharusnya dimulai dengan huruf kapital dan pada kalimat langsung. Misalnya penulisan nama tokohtokoh dalam cerita : Gangsa, Putri Malu, Negeri Banjit, Tuhan, Negeri Kasui; 2) Kesalahan menggunakan tanda baca titik, koma dan tanda baca tanda seru maupun tanda tanya pada penulisan kalimat langsung; 3) Kesalahan penggunaan kata tidak baku seperti:

“Tak lama berjalan, ia mendengar..”( 21A/3),

"Ketika mereka lagi duduk... "( 21A/2),

"Ia kaget mendapati ibu kota Negeri Banjit..". $(10 \mathrm{~A} / 8)$

"Ia baru mempelajari bagaimana cara memiliki rasa rendah hati." (53A/2)

"Karena muka bayi itu mirip dengan ayahnya" $(16 \mathrm{~A} / 2)$

4) Diksi atau pilihan kata. Terdapat 2 jenis kesalahan diksi. Yaitu pilihan kata yang tidak sesuai secara pemaknaan dan dan tidak sesuai dengan tema. Contoh kesalahan pemilihan kata yang tidak sesuai secara pemaknaan pada kutipan berikut :

"Akhirnya Gangsa dibawa ke kerajaan" (35A/8)

"Negeri Banjit menyuruh Gangsa pulang" $(35 \mathrm{~A} / 9)$

"Suara kukuruyuk pun berbunyi, hari pun menjadi pagi" (28A/1)

"Akhirnya raksasa itu terjatuh dan tidak bisa membangunkan badannya lagi" (5A/3)

Kata dibawa kurang tepat digunakan dalam kalimat tersebut. Karena pada teks asli, tertulis "Prajurit itu memperkenalkan Gangsa kepada sang Raja". Kata "dibawa: tidak sepadan dengan kata memperkenalkan, dan makna pasif menimbulkan pemaknaan negatif pada karakter tokoh Gangsa.

Begitu juga kata berimbuhan "menyuruh" tidak sepadan menggantikan kata mengizinkan seperti pada teks asli. Kata dibawa lebih tepat untuk benda mati atau dalam konteks cerita tersebut, misalnya untuk tawanan. Kata "berbunyi" tidak tepat digunakan seharusnya kata "terdengar", sedangkan frasa" hari menjadi pagi" tidak lazim digunakan. Frasa tersebut dapat digantikan dengan "pagi menjelang". Kata "membangunkan" dapat digantikan dengan kata "bangun" atau bangkit. Sedangkan Kesalahan pemilihan kata yang tidak sesuai dengan tema cerita ialah :

"Gangsa akhirnya mendapat ide untuk.."(14 $\mathrm{A} / 8$ )

"Seorang wanita tersenyum bahagia" (19A/1)

Kata ide kurang padu digunakan dalam konteks cerita. Kata akal lebih sesuai dengan setting dan latar cerita Hikayat Gangsa dan Puteri Malu. Kata "wanita" akan lebih padu jika diganti dengan kata "perempuan" 5) kesalahan dalam imbuhan atau afiksasi ialah seperti kutipan berikut :

"Gangsa pun mensetujui permintaan lelaki separuh baya itu. " (28A/3)

Bentuk afiksasi pada kata "mensetujui' seharusnya "menyetujui". Awalan memengalai proses morfemis apabila bertemu dengan kata diawali dengan huruf $s$, akan berubah menjadi $n y$, sehingga bukan "mensetujui" tetapi "menyetujui".

\section{Gaya penuturan}

Gaya penuturan atau penceritaan berkaitan dengan penggunaan sudut pandang, dan pemilihan kata. Gaya penuturan dalam teks ringkasan mengikuti gaya penceritaan pada teks asli. Semua siswa mendapatkan skor 4, dengan gaya penceritaan menggunakan penceritaan sudut pandang orang ketiga. Hal tersebut dapat dilihat dari penyebutan nama tokoh-tokoh dalam cerita seperti Gangsa, Ibu Miah, Kakek, Puteri Malu, Baginda Raja, lelaki paruh baya dan penggunaan kata ganti "Ia". Kesalahan yang ditemukan pada setiap teks ringkasan tidak lebih dari lima kesalahan. 
Berikut beberapa kesalahaan gaya penceritaan yang menggunakan sudut pandang orang kedua :

" Sekarang usia Gangsa sudah sepuluh tahun $(19 \mathrm{~A} / 2)$

" Almarhum suaminya telah meninggal beberapa tahun yang lalu" (20A/1)

Penggunaan kata dan frasa yang berfungsi sebagai keterangan waktu tersebut tidak tepat karena keduanya digunakan utuk penceritaan sudut pandang orang kedua.

Gaya penuturan juga dapat dilihat dari diksi yang sesuai dengan tema cerita. Diksi tersebut banyak diambil dari teks cerita. Penulis menggunakan kembali diksi yang terdapat pada teks cerita untuk menulis ringkasan. Namun, penulis juga menggunakan kosa kata yang berasal dari pengetahuan yang dimiliki, di antaranya sebagai berikut :

"Pagi yang cerah menghiasi Negeri Kasui. Salah satu rumah di Negeri Kasui itu terlihat bahagia, karena telah lahir seorang bayi tampan. Rumah itu adalah rumah Ibu Miah. Bayi lelaki tampan itu diberi nama Gangsa.” (10A/1)

Penggunaan partikel pun dan lah dalam ringkasan. Penggunaan pertikel dapat memberikan nuansa tertentu pada penceritaan dalam ringkasan. Seperti kutipan berikut :

" Gangsa pun melanjutkan perjalanan (8A/3)

"Kemudian tiba-tiba datanglah kawanan raksasa itu untuk mengambil seratus ekor sapi..”(10A/5)

Dilihat dari sebaran perolehan nilai, 23 (77\%) mahasiswa termasuk kategori sangat baik, yaitu terdiri dari 5 mahasiswa masuk kategori sangat baik mencapai nilai 95, 3 mahasiswa mencapai nilai 90,5 mahasiswa mencapai nilai 85, 10 mahasiswa mencapai nilai 80 . Kemudian 4 (13\%) mahasiswa masuk kategori baik, terdiri dari 2 mahasiswa meraih nilai 75,2 mahasiswa meraih nilai 70 . Kemudian, 3 siswa (10\%) masuk kategori cukup, 1 siswa mendapat nilai 65 dan 2 siswa mendapat nilai 60 . Kemudian rata-rata nilai sebesar 81,5 masuk kategori sangat baik.

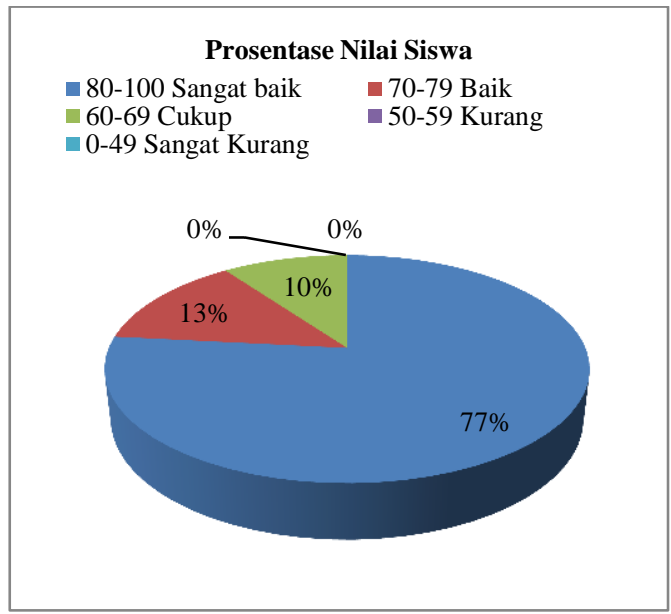

Gambar 2. Persentase Nilai Siswa

\section{KESIMPULAN}

Berdasarkan hasil analisis dengan mengacu pada lima aspek, yaitu kesesuaian isi, pemilihan detail cerita, pengembangan alur, ketepatan kata dan kalimat, dan gaya bahasa, maka dapat simpulkan bahwa :

1. Pada umumnya siswa memiliki kemampuan yang sangat baik dalam meringkas teks cerita hal ini dilihat dari nilai rata-rata sebesar 81,5.

2. Semua siswa memiliki gaya penceritaan yang sangat baik.

3. Siswa lebih mengutamakan kesesuaian isi cerita dan ketepatan ejaan dalam menulis terabaikan. Hal ini dikarenakan di antara kelima aspek, capaian skor 4 pada aspek kata dan tata kalimat ialah paling rendah. Kesalahan penggunaan tanda baca titik, koma, dan huruf kapital. Selain itu, juga ditemukan banyak penggunaan kata tidak baku yang berasal dari bahasa ibu, dan juga penggunaan diksi tidak sesuai dengan tema cerita dan juga kesalahan tata bahasa.

Dengan demikian, guru perlu menekankan lagi pentingya ejaan dalam menulis dalam pembelajaran bahasa Indonesia. Hal tersebut dapat dilakukan dengan sosialisasi dan pemberian latihan-latihan untuk meningkatkan kesadaran siswa terhadap pentingnya ejaan dan tata kalimat dalam menulis.

\section{REFERENSI}

Ampuni, S. (2008). Proses Kognitif dalam Pemahaman Bacaan. Buletin Psikologi Fakultas Psikologi UGM, Tahun VI, No. 2 Desember hal. 16- 
26.

30-37.

Anderson, L. W et al. (2010). Kerangka

Landasan untuk Pembelajaran,

Pengajaran, dan Asesmen Revisi

Taksonomi. Yogyakarta: Pustaka

Pelajar.

Arikunto, S. (2010). Prosedur Penelitian Suatu Pendekatan Praktik (Edisi Revisi). Jakarta: Rineka Cipta

Dalman. (2014). Keterampilan Menulis. Jakarta: PT Raja Grafindo Persada.

Isdriani, Pudji. (2009). Seribu Pena Bahasa Indonesia. Jakarta: Erlangga

(2010). Argumentasi dan Narasi. Jakarta: PT Gramedia.

Mahpi, Roekhan, \& Widiati, N. (2017). "Strategi Kognitif Kata Kunci Yang Digunakan Siswa Kelas VII SMP Dalam Penulisan Teks Deskriptif". Jurnal Pendidikan: Teori, Penelitian, dan Pengembangan Vol. 2, (9), 1262-1269.

Nurgiantoro, B. (2014). Penilaian Pembelajaran Bahasa Berbasis Kompetensi. Yogyakarta: BPFE

Nurhadi. (2010). Bagaimana Meningkatkan Kemampuan Membaca?. Malang: Sinar Baru Algensindo

Olivia, Femi. (2009). Teknik Meringkas. Jakarta: PT. Elex Media Komputindo

Sibarani, B. (2017). "Penerapan Proses Kognitif dan Terapi Cognitive Blocking Dalam Peningkatan Kualitas Pembelajaran Menulis". Jurnal diksi, Vol.14 (2), 132-142.

Saddhono, Kundharu. (2014). Pembelajaran Keterampilan Berbahasa Indonesia. Yogyakarta: GRAHA ILMU.

Rahmadani, S., Suhartono, \& Arifin, M. (2017). "Kemampuan Menulis Teks Narasi Tentang Pengalaman Libur Sekolah Siswa Kelas VII SMP Negeri 1 Bermani Ilir Kabupaten Kepahiang”. Jurnal Ilmiah Ilmiah Korpus FBS UNIB. Volume I(2), 218-222.

Tarigan, H.G. (2013). Menulis Sebagai Suatu Keterampilan Berbahasa. Bandung : Angkasa

Wahyu, S., Taib, R., \& Subhayni. (2017). "Kemampuan Siswa Kelas VII MTsN Meuraxa Banda Aceh Meringkas Teks Laporan Hasil Observasi”. Jurnal Ilmiah Mahasiswa Jurusan PBSI UNSYIAH,Vol.2(1) 